\title{
Fish assemblage of the Mamanguape Environmental Protection Area, NE Brazil: abundance, composition and microhabitat availability along the mangrove-reef gradient
}

\author{
Josias Henrique de Amorim Xavier ${ }^{1}$, Cesar Augusto Marcelino Mendes Cordeiro², \\ Gabrielle Dantas Tenório ${ }^{1}$, Aline de Farias Diniz ${ }^{1}$, Eugenio Pacelli Nunes Paulo Júnior ${ }^{1}$, \\ Ricardo S. Rosa ${ }^{1}$ and Ierecê Lucena Rosa ${ }^{1}$
}

Reefs, mangroves and seagrass biotopes often occur in close association, forming a complex and highly productive ecosystem that provide significant ecologic and economic goods and services. Different anthropogenic disturbances are increasingly affecting these tropical coastal habitats leading to growing conservation concern. In this field-based study, we used a visual census technique (belt transects $50 \mathrm{~m} \times 2 \mathrm{~m}$ ) to investigate the interactions between fishes and microhabitats at the Mamanguape Mangrove-Reef system, NE Brazil. Overall, 144 belt transects were performed from October 2007 to September 2008 to assess the structure of the fish assemblage. Fish trophic groups and life stage (juveniles and adults) were recorded according to literature, the percent cover of the substrate was estimated using the point contact method. Our results revealed that fish composition gradually changed from the Estuarine to the Reef zone, and that fish assemblage was strongly related to the microhabitat availability, as suggested by the predominance of carnivores at the Estuarine zone and presence of herbivores at the Reef zone. Fish abundance and diversity were higher in the Reef zone and estuary margins, highlighting the importance of structural complexity. A pattern of nursery area utilization, with larger specimens at the Transition and Reef Zone and smaller individuals at the Estuarine zone, was recorded for Abudefduf saxatilis, Anisotremus surinamensis, Lutjanus alexandrei, and Lutjanus jocu. Our findings clearly suggests ecosystem connectivity between mangrove, seagrass and reef biotopes, and highlighted the importance of Mamanguape Mangrove-Reef System as a priority area for conservation and research, whose habitat mosaics should be further studied and protected.

Recifes, manguezais e bancos de fanerógamas marinhas são biótopos frequentemente associados, formando um ecossistema complexo e altamente produtivo que proporciona significativos bens e serviços ecológicos e econômicos. Diferentes impactos antrópicos estão crescentemente afetando esses habitats costeiros tropicais, trazendo preocupações acerca de sua conservação. Neste estudo de campo, utilizamos uma técnica de censo visual subaquático (transecções de 50 x 2 m) para investigar as interações entre os peixes e microhabitats no complexo estuarino-recifal de Mamanguape, no Nordeste do Brasil. Entre outubro de 2007 e setembro de 2008 foram realizadas 144 transecções para avaliar a estrutura da assembleia de peixes. Grupos tróficos e estágios de vida dos peixes (jovens e adultos) foram registrados segundo a literatura, enquanto a porcentagem de cobertura do substrato foi estimada através do método de pontos de contato. Nossos resultados mostraram que a composição da ictiofauna mudou gradualmente da Zona Estuarina para a Zona Recifal, e que a assembleia de peixes esteve fortemente relacionada com a disponibilidade de microhabitats - como sugerido pela predominância de carnívoros na zona estuarina e presença de herbívoros na zona recifal. A abundância e diversidade de peixes foram maiores na zona recifal e nas margens do estuário, destacando a importância da complexidade estrutural. O padrão de uso da área como berçário, com indivíduos maiores nas zonas de transição e recifal, e os menores na zona estuarina, foi registrado para Abudefduf saxatilis, Anisotremus surinamensis, Hippocampus reidi, Lutjanus alexandrei e Lutjanus jocu. Nossos resultados sugerem que há conectividade entre os biótopos de manguezal, bancos de fanerógamas e recifes, e destacam a importância do Sistema Manguezal-Recife de Mamanguape como uma área prioritária para conservação e pesquisa, cujos mosaicos de habitats devem ser ainda estudados e protegidos.

Key words: Conservation, Conservation unit, Ichthyofauna, Nursery habitats.

\footnotetext{
${ }^{1}$ Universidade Federal da Paraíba, CCEN, Departamento de Sistemática e Ecologia, Campus I, s/nº Cidade Universitária, 58059-900 João Pessoa, PB, Brazil.josiasxavier@gmail.com(JHAX), gabidt@gmail.com(GDT), dinizbio@yahoo.com.br(AFD), eugenioepacelli@gmail.com (EPNPJ),rsrosa7@yahoo.com.br (RSR), ierecerosa@yahoo.com.br (ILR)

${ }^{2}$ Universidade Federal Fluminense, Departamento de Biologia Marinha, Outeiro São João Batista, s/nº, Centro, 24020-141 Niterói, RJ, Brazil.cammcordeiro@gmail.com (CAMMC)
} 


\section{Introduction}

Reefs, mangroves and seagrass beds are the major coastal habitats in tropical areas (Nagelkerken et al., 2000; Ikejima et al., 2003; Mumby et al., 2004; Mumby et al., 2008; Nagelkerken \& Faunce, 2008; Nagelkerken et al., 2008). They often occur in close association, forming a complex and highly productive ecosystem that provide significant economic goods and services and contribute to the livelihoods, food security and safety of millions of people around the world (Moberg \& Folke, 1999; Nagelkerken et al., 2008; Unsworth et al., 2009). Several anthropogenic disturbances are increasingly affecting those coastal habitats (see Rönnbäch, 1999), leading to growing conservation concern.

Reefs are known for the diversity and abundance of their fish and invertebrate faunas, while seagrass beds and mangrove areas are recognized as important nursery areas for many commercially important and forage organisms (Nagelkerken et al., 2008), as well as to some of the reef species (Ogden \& Gladfelter, 1983). Mangroves are also characterized by a high abundance of fish, crustaceans and mollusks (Nagelkerken et al., 2008).

Many studies have long discussed the nursery role of mangroves and estuaries (Ogden \& Gladfelter, 1983; Arrivillaga \& Baltz, 1999; Nagelkerken et al., 2000; Ikejima et al., 2003; Mumby et al., 2004; Nagelkerken \& Faunce, 2008), and how juvenile fish use habitats like seagrass beds and small, protected patch reefs before venturing out to large reefs. In that line, some studies have suggested that current rates of mangrove deforestation are likely to have severe deleterious consequences for the ecosystem function, fisheries productivity and resilience of adjacent reefs (Mumby et al., 2004; Mumby \& Hastings, 2008).

Knowledge on the nursery function and connectivity of mangroves to other habitats, however, is limited, particularly in areas outside of the Caribbean (Nagelkerken et al., 2000), therefore, studies focusing on the functional roles played by species in those habitats, are relevant to increase our knowledge about on how habitat mosaics must be protected if a complete protection of biodiversity is to be achieved (see Gray, 1997).

In this field-based study, we used visual census methods to investigate the interactions between fishes and microhabitats at the Mamanguape Mangrove-Reef system (NE Brazil). Published information on the fish fauna of this area is limited to the report of species collected by the BrannerAgassiz Expedition (Gilbert, 1900) and the papers based on an ethnoecological perspective (Mourão \& Nordi, 2003; Rocha et al., 2008). Other recent reports on the estuarine and reef fishes remained unpublished (Rosa \& Sassi, 2002; Silva, 2002).

Considering the Mamanguape Mangrove-Reef system, with the presence of estuary and reefs as adjacent ecosystems and exposed to similar environmental conditions, this study addressed the following questions: (1) are there differences (e.g., composition, trophic levels, abundance) in the fish assemblages distributed along the estuarine-reef gradient? (2) how does microhabitat availability influence the spatial distribution of fishes? (3) does structural complexity, herein inferred by rugosity, also influence fish assemblage composition? (4) based on the ontogenetic distribution of fishes, is there indication of connectivity between the Mamanguape mangrove estuary and the adjacent rocky reef ecosystem?

\section{Material and Methods}

Study area. The Mamanguape Mangrove-Reef system (NE Brazil) is located at the north coast of Paraíba State, within the boundaries of an Environmental Protection Area considered as a high priority site for biodiversity conservation in Brazil (Ministry of the Environment, 2002). The Mamanguape estuary (06 $46^{\prime} 20^{\prime}$ 'S $\left.34^{\circ} 56^{\prime} 00^{\prime \prime} \mathrm{W}\right)$ is bordered by a dense mangrove forest, its mouth being partially dammed by a fringe reef, visible at low tide, which extends north up to $8.5 \mathrm{Km}$ (Silva, 2002). Data were collected in five sub-areas (Fig. 1), categorized according to their habitat features, including margin characteristics, bottom type and human use, as summarized in Table 1. Sampling stations referred to as Tanques, Peixe-Boi and Cação sub-areas collectively represent mangrove habitats, and were categorized as the Estuarine zone. The Transition sub-area, herein called Transition zone, was delimited as a sandy beach area, adjacent to the Reef sub-area, herein called Reef zone, formed by a fringe

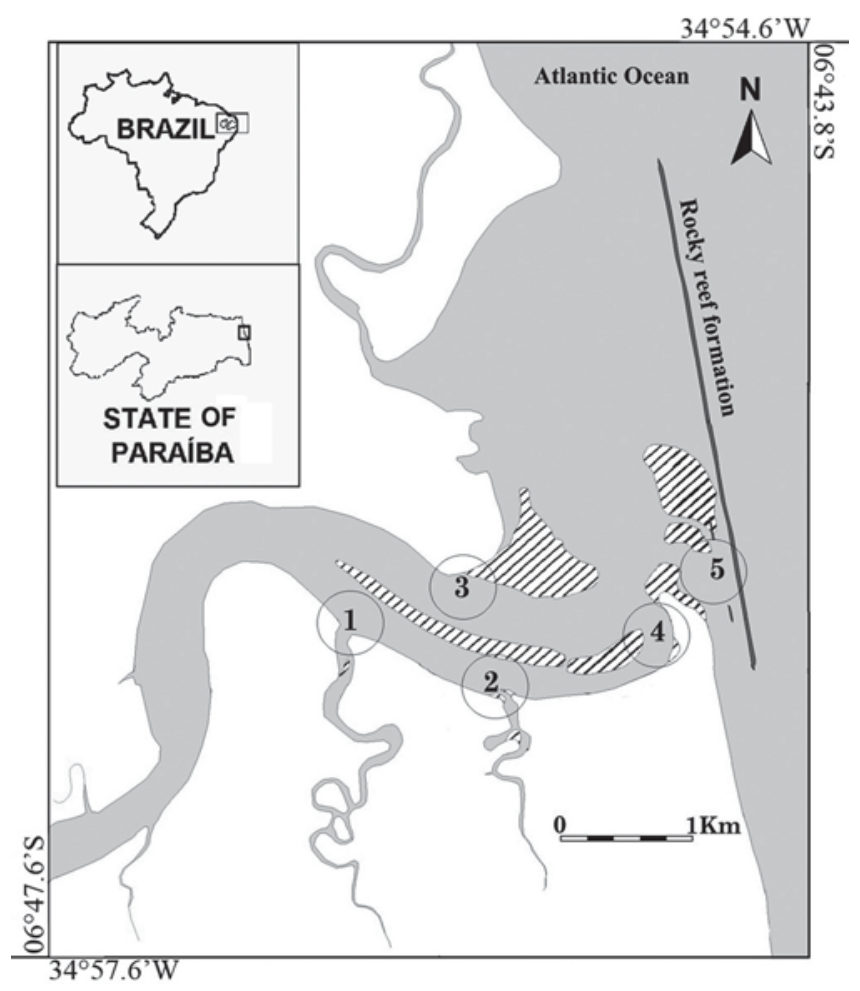

Fig. 1. Mamanguape estuary, State of Paraíba, NE Brazil, showing surveyed sub-areas: 1) Tanques; 2) Peixe-Boi; 3) Cação; 4) Transition; and 5) Reefs. Dashed areas represent sandbanks. 
Table 1. Habitat features of studied sub-areas in the Mamanguape Mangrove-Reef system, State of Paraíba, NE Brazil, according to margin and bottom types, depth, currents, sedimentation, and human use. Sub-areas: 1 . Ta - Tanques; 2 . Pe Peixe-Boi; 3. Ca-Cação; 4. Tr-Transition; 5. Re-Reefs.

\begin{tabular}{|c|c|c|c|c|c|}
\hline Sub-area & Margin & Bottom & Exposure & $\begin{array}{l}\text { Maximum } \\
\text { depth }\end{array}$ & Human use/ boats \\
\hline $1 \mathrm{Ta}$ & $\begin{array}{c}\text { Well preserved } \\
\text { mangrove vegetation }\end{array}$ & $\begin{array}{l}\text { Sand and } \\
\text { mud }\end{array}$ & Calm and sheltered & $6 \mathrm{~m}$ & $\begin{array}{c}\text { Artisanal fisheries: cast-net and gill-net; Shellfish harvesting; } \\
\text { transportation of tourists by local sail boats }\end{array}$ \\
\hline $2 \mathrm{Pe}$ & $\begin{array}{l}\text { Well preserved } \\
\text { mangrove vegetation }\end{array}$ & $\begin{array}{l}\text { Sand and } \\
\text { mud }\end{array}$ & Calm and sheltered & $4 \mathrm{~m}$ & $\begin{array}{l}\text { Artisanal fisheries: cast-net and gill-net; transportation of tourists } \\
\text { by local sail boats }\end{array}$ \\
\hline $3 \mathrm{Ca}$ & $\begin{array}{l}\text { Sparse and lower } \\
\text { mangrove vegetation }\end{array}$ & $\begin{array}{l}\text { Sand and } \\
\text { mud }\end{array}$ & $\begin{array}{l}\text { Unsheltered; exposed to } \\
\text { currents }\end{array}$ & $4 \mathrm{~m}$ & $\begin{array}{c}\text { Artisanal fisheries: cast-net; Shellfish harvesting; Transportation } \\
\text { of tourists by local sail boats }\end{array}$ \\
\hline $4 \mathrm{Tr}$ & Beach area & Sand & $\begin{array}{l}\text { Unsheltered; exposed to } \\
\text { currents }\end{array}$ & $4 \mathrm{~m}$ & $\begin{array}{l}\text { Artisanal fisheries: cast-net and gill-net; larger-scale tourism, } \\
\text { including the presence of motorized boats. Fishing boats stored in } \\
\text { huts built along the margins. }\end{array}$ \\
\hline $5 \mathrm{Re}$ & $\begin{array}{l}\text { Rocky reef area, } 200 \\
\mathrm{~m} \text { far from the } \\
\text { beach. }\end{array}$ & $\begin{array}{l}\text { Sand and } \\
\text { rocks }\end{array}$ & $\begin{array}{l}\text { Unsheltered; exposed to } \\
\text { currents, except inside tide } \\
\text { pools }\end{array}$ & $6 \mathrm{~m}$ & $\begin{array}{c}\text { Recreational fishing (fish rods); presence of sail and motorized } \\
\text { boats. }\end{array}$ \\
\hline
\end{tabular}

rocky reef. Sampling points and margin limits, including sandbanks, when appropriate, were recorded using GPS and plotted on a georeferenced map using the software AutoCAD ${ }^{\circledR}$ 2005.

Fish assemblage composition and spatial distribution. Data on fish assemblage composition and abundance were recorded from October 2007 to September 2008, during low tide, on neap tides. Throughout the study 144 belt transects $(50 \times 2 \mathrm{~m})$ were performed, covering non-overlapping areas through SCUBA diving, totaling an area of 14,400 $\mathrm{m}^{2}$. All transects were conducted during daylight between 07:00 am $\mathrm{h}$ and 05:00 $\mathrm{pm}$ h. Due to the shade and decreased visibility at the mangroves, which ranged from zero to $2 \mathrm{~m}$ in the study area, fish were counted within $1 \mathrm{~m}$ either side of the transect.

Transects were distributed across sampling sub-areas as follows: 1) Tanques, $\mathrm{n}=40$ transects; 2) Peixe-Boi, $\mathrm{n}=28$; 3 ) Cação, $n=30 ; 4$ ) Transition, $n=29$, and 5) Reefs, $n=17$. Transects were separated from one another by approximately $50 \mathrm{~m}$, and encompassed both margin and channel portions of the estuary. Surveys were undertaken in both dry (September to February) and rainy seasons (March to August). Tanques, Peixe-Boi and Transition sub-areas were sampled from October 2007 to April 2008, while Cação and Reefs sub-areas were sampled from April to September 2008. Each sub-area was sampled in both seasons.

Fishes sighted on transects were quantified, categorized by size classes and then classified as juveniles or adults, according to information on their size at first maturity (Thomsom et al., 2000; Dias et al., 2005; Rosa et al., 2007; Souza et al., 2007; Souza \& Chaves, 2007; Afonso et al., 2008; Poot-Salazar et al., 2009; Froese \& Pauly, 2010). When size at first maturity was not available for a species, we used data from another species of the same genus as a reference point. Reported fish sizes are total length (TL) in $\mathrm{cm}$. Since our size data did not fit to normal distribution, they were compared between sub-areas by using Mann-Whitney Test (nonparametric analysis). Statistical analyses were performed using Statistica ${ }^{\circledR}$ Software, version 6.0 (Statsoft, 2004). Confidence level was defined as $95 \%$.
Species were also checked on their trophic group and categorized as omnivores, carnivores, invertivores of mobile prey, invertivores of sessile prey, roving herbivores, and territorial herbivores, based on the literature (Randall, 1967; Ferreira et al., 2001, 2004; Guedes et al., 2004; Froese \& Pauly, 2010). Individuals of Stegastes variabilis were categorized as invertivores of mobile prey when juveniles and as territorial herbivores when adults (Froese \& Pauly, 2010). Taxa that could not be visually identified with confidence to species level are cited by genus only, which was the case of Antennarius sp., Centropomus sp., Mugil sp., Scarus sp., Sparisoma sp., and Strongylura sp.

Percentage cover of benthic organisms and of other items found on the substrate was estimated using the point contact method (Ferreira \& Maida, 2006), in which 100 points were distributed at $0.50 \mathrm{~m}$ intervals, along the same transect used to assess fish abundance. Substrate characteristics found at the pre-defined points were recorded and classified into categories: sand/ muddy, mangrove, seagrass, bivalves, sessile invertebrates, macroalgal beds and other algae.

Topographic complexity of the bottom (rugosity) was estimated using the 'chain link method' (adapted from Luckhurst \& Luckhurst, 1978), as follows: a chain of 5 m was draped over the substrate, to conform as close as possible to all contours and crevices, and a measure of the actual surface distance relative to the linear distance was thus obtained. This measure is termed the rugosity index. Salinity was also measured for each transect with a portable refractometer.

Canonical Correspondence Analyses (CCA) were performed to describe the relationship between microhabitats categories and individual fish species, where fishes are presented as symbols and microhabitats as environmental vectors. For environmental data, we used the following categories, based on our substrate data: MUDDYSAND sandy or muddy bottom, without visually detectable organisms; MANGROVE - roots, leaves and fallen branches of mangrove trees, mainly Rhizophora mangle; SEAGRASS - Halophila sp. and Halodule wrightii; BIVALVES - bivalve shells, mainly Crassostrea rhizophorae, Anomalocardia 
brasiliana, and Lucina pectinata; SESSILE INV - sponges, including Haliclona sp., Cinachyrella alloclada, and cnidarians, including Carijoa sp.; ALGAE - included macroalgal beds, mainly composed by Hypnea musciformis, Hypnea spinella, Cryptonemia sp., and Acanthophora sp., and other drift or attached algae but not forming beds, which included Gracilaria sp., Gelidiella acerosa, Pterocladia sp., Gelidium sp., Corynomorpha sp., and Acetabularia sp. The proximity of symbols to the vectors indicates the relationship between fishes and environmental variables. Abundance data were $\log$ transformed to improve fit to Normality, and rare species (only sighted once in transects) were excluded from the analysis. A Monte-Carlo randomization test (999 permutations) was used to assess the probability of the observed pattern being due to chance (see Ter Braak, 1986).

\section{Results}

Fish abundance and composition. The fish assemblage recorded during the underwater surveys in the study area was represented by 37 species distributed in 23 families, as shown on Table 2. In addition to the fish species found within the area covered by transects, we recorded the presence of four other species along the margins of the Estuarine zone: Antennarius sp., Gymnothorax funebris, Sphoeroides greeleyi, and Strongylura sp. These, however, did not enter the analyses.

Overall, Abudefduf saxatilis, Anisotremus surinamensis, Eucinostomus melanopterus, and Lutjanus alexandrei were the most abundant species; their abundance, however, was unequally distributed according to sub-area and to microhabitat features. The Reef zone exhibited the highest fish abundance, mainly represented by Abudefduf saxatilis and Anisotremus surinamensis. Also, the abundance and diversity of fishes were higher during the rainy season (from March to August 2008). Fish abundance and population densities (number of individuals per transect), as well as size parameters (mean ${ }^{ \pm}$standard deviation), are given for each sub-area during dry (Table 3 ) and rainy season (Table 4).

The majority of individuals (77.1\%) recorded at the study site were considered juveniles, and were sighted throughout the year, including Eucinostomus melanopterus and Lutjanus spp., which are important species for the local artisanal fisheries. Eleven species were exclusively represented by juveniles (Acanthurus chirurgus, Centropomus sp., Chaetodon striatus, Haemulon parra, Lutjanus alexandrei, L. analis, Ocyurus chrysurus, Rypticus randalli, Scarus sp., Sparisoma sp., and Trachinotus falcatus), while six (Achirus lineatus, Chaetodipterus faber, Dactylopterus volitans, Dasyatis guttata, Mugil sp., and Ophichthus ophis) were represented exclusively by adults. Life stage of species Thalassophryne nattereri, Pareques acuminatus, Myrichthys ocellatus, and Echeneis naucrates could not be assessed.

Percentage cover of the substrate. Benthic organisms and other items found on the substrate were grouped into categories, as summarized in Table 5. Substrate in Estuarine and Transition zones was formed by sand and mud, and covered by leaves of Rhizophorae mangle, fallen branches of mangrove vegetation and bivalve shells, mainly Anomalocardia brasiliana. Structural complexity at these sub-areas was enhanced by mangrove vegetation (margins), or by fallen logs, branches or rocks (channel). Seagrass beds were commonly found in the Tanques and Peixe-Boi sub-areas, while the Cação sub-area was dominated by bivalve shells and lacked seagrass beds. Unlike the Estuarine zone, transition zone lacked mangrove-related components along the margin, being characterized by strong tidal currents and sandy areas. Fallen logs and branches with attached sessile invertebrates (cnidarians, sponges, polychaetes, and barnacles) were also found there.

The Reef zone was covered by a more diverse group of items, including several species of macroalgae, mostly Hypnea musciformis and Cryptonemia sp., sessile invertebrates and rocks. Structural complexity in this sub-area was increased by the presence of large rocks found on the sandy bottom.

Salinity ranged from 20 to 43 at the Estuarine zone, while at the Transition and Reef zones it ranged from 31 to 41, a narrower range (Table 5). On the other hand, the structural complexity (rugosity) of Estuarine and Transition zones was similarly low (0.11 to 0.12$)$, while Reef zone presented much higher values (1.13).

Spatial distribution of the fish assemblage. Along the Estuarine zone, we recorded 21 fish species, from which six were exclusively sighted there: Acanthurus bahianus, Centropomus sp., Chaetodipterus faber, Dactylopterus volitans, Dasyatis guttata, and Ophichthus ophis.

Juveniles of Centropomus sp. were sighted at the Estuarine zone from October to November 2007 (dry season). Fish abundance and diversity were higher along the margin, in mangrove-rich portions of the estuary used as microhabitats, mostly by Hippocampus reidi, Lutjanus alexandrei, L. analis, L. jocu, and Bathygobius soporator. Bathygobius soporator and the seahorse Hippocampus reidi were frequently found in association with mangrove roots, oysters, sessile invertebrates and seagrass beds. Juveniles of Lutjanus were frequently sighted in proximity to mangrove roots. Rypticus randalli (sighted at all surveyed zones, generally associated to muddy or sandy bottom) and Echeneis naucrates (sighted at the Estuarine and Transition zones) occurred in the estuary channel. The adult life stage of Eucinostomus melanopterus was also exclusive found in the Estuarine zone.

The species Achirus lineatus, Bathygobius soporator (from these two only adults recorded), and Citharichthys spilopterus (only juveniles), although mostly found at the Estuarine zone, also occurred in the transition zone. The Transition zone received influence from both estuarine and reef systems, and the 18 species found there also occurred in the Estuarine zone, Reef zone or on both. The highest abundances were obtained for Eucinostomus melanopterus, commonly found in the Estuarine zone, Abudefduf saxatilis and Anisotremus surinamensis, the most abundant species 
Table 2. Information on family and species, total abundance, trophic group, and maturity size of fishes sighted in the Mamanguape estuary, State of Paraíba, NE Brazil, from October 2007 to September 2008. * Trophic group (TG): CA - carnivore; IM - invertivore of mobile prey; IS - invertivore of sessile prey; RH - roving herbivore; TH - territorial herbivore; OM omnivore. ${ }^{*}$ When size at first maturity was not available for the sighted species, it was inferred from other species from the same genus, which were Abudefduf vaigiensis, Anisotremus davidsonii, Centropomus undecimalis, Eucinostomus gula, Haemulon plumierii, Mugil curema, Ophichthus gomesii, Scarus coeruleus, and Stegastes variabilis. Size at maturity not available for Thalassophryne nattereri, Pareques acuminatus, Myrichthys ocellatus, and Echeneis naucrates. Maturity

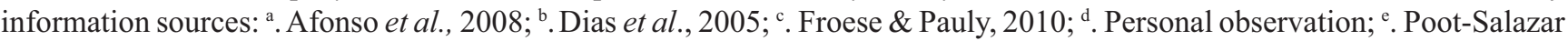
et al., 2009; ${ }^{\mathrm{f}}$. Rosa et al., 2007; ${ }^{\mathrm{g}}$. Souza et al., 2007; ${ }^{\mathrm{h}}$. Souza \& Chaves, 2007; ${ }^{\mathrm{i}}$. Thomsom et al., 2000.

\begin{tabular}{|c|c|c|c|c|}
\hline Family & Species & Total abundance & TG* & Maturity $(\mathrm{cm}) * *$ \\
\hline Pomacentridae & Abudefduf saxatilis & 250 & $\mathrm{OM}$ & $12.0^{\mathrm{c}}$ \\
\hline Haemulidae & Anisotremus surinamensis & 186 & $\mathrm{IM}$ & $5.0^{\mathrm{i}}$ \\
\hline Gerreidae & Eucinostomus melanopterus & 66 & $\mathrm{IM}$ & $11.0^{\mathrm{c}}$ \\
\hline Lutjanidae & Lutjanus alexandrei & 34 & $\mathrm{CA}$ & $30.0^{\mathrm{c}}$ \\
\hline Scaridae & Sparisoma sp. & 32 & RH & $21.9^{\mathrm{a}}$ \\
\hline Lutjanidae & Lutjanus jocu & 26 & $\mathrm{CA}$ & $30.0^{\mathrm{c}}$ \\
\hline Serranidae & Rypticus randalli & 15 & $\mathrm{CA}$ & $10.9^{\mathrm{h}}$ \\
\hline Pomacentridae & Stegastes variabilis & 15 & $\mathrm{IM} / \mathrm{TH}$ & $6.2^{\mathrm{g}}$ \\
\hline Gobiidae & Bathygobius soporator & 15 & IM & $7.0^{\mathrm{d}}$ \\
\hline Syngnathidae & Hippocampus reidi & 14 & IM & $10.0^{\mathrm{f}}$ \\
\hline Pomacentridae & Stegastes fuscus & 13 & $\mathrm{TH}$ & $6.2^{\mathrm{g}}$ \\
\hline Acanthuridae & Acanthurus coeruleus & 13 & RH & $11.0^{\mathrm{c}}$ \\
\hline Centropomidae & Centropomus sp. & 12 & $\mathrm{CA}$ & $30.0^{\mathrm{c}}$ \\
\hline Lutjanidae & Lutjanus analis & 9 & $\mathrm{CA}$ & $38.0^{\mathrm{c}}$ \\
\hline Gobiidae & Coryphopterus glaucofraenum & 8 & $\mathrm{OM}$ & $2.0^{\mathrm{c}}$ \\
\hline Tetraodontidae & Sphoeroides testudineus & 8 & $\mathrm{IM}$ & $13.0^{\mathrm{c}}$ \\
\hline Haemulidae & Anisotremus virginicus & 7 & IM & $5.0^{\mathrm{i}}$ \\
\hline Serranidae & Epinephelus adscensionis & 6 & CA & $25.0^{\mathrm{c}}$ \\
\hline Haemulidae & Haemulon parra & 6 & IM & $16.0^{\mathrm{c}}$ \\
\hline Scaridae & Scarus sp. & 6 & $\mathrm{RH}$ & $30.5^{\mathrm{c}}$ \\
\hline Achiridae & Achirus lineatus & 6 & IM & $3.1^{\mathrm{e}}$ \\
\hline Dactylopteridae & Dactylopterus volitans & 4 & IM & $8.9^{\mathrm{h}}$ \\
\hline Echeneidae & Echeneis naucrates & 4 & $\mathrm{CA}$ & - \\
\hline Syngnathidae & Microphis brachyurus & 3 & IM & $12.0^{\mathrm{c}}$ \\
\hline Ophichthidae & Myrichthys ocellatus & 2 & IM & - \\
\hline Carangidae & Trachinotus falcatus & 2 & IM & $44.9^{\mathrm{c}}$ \\
\hline Acanthuridae & Acanthurus bahianus & 2 & $\mathrm{RH}$ & $9.0^{\mathrm{c}}$ \\
\hline Paralichthyidae & Citharichthys spilopterus & 2 & IM & $11.7^{\mathrm{b}}$ \\
\hline Dasyatidae & Dasyatis guttata & 1 & $\mathrm{CA}$ & $66.0^{\mathrm{c}}$ \\
\hline Ophichthidae & Ophichthus ophis & 1 & CA & $4.7^{\mathrm{h}}$ \\
\hline Batrachoididae & Thalassophryne nattereri & 1 & $\mathrm{IM}$ & - \\
\hline Mugilidae & Mugil sp. & 1 & RH & $12.0^{\mathrm{c}}$ \\
\hline Lutjanidae & Ocyurus chrysurus & 1 & $\mathrm{CA}$ & $13.0^{\mathrm{c}}$ \\
\hline Sciaenidae & Pareques acuminatus & 1 & $\mathrm{CA}$ & - \\
\hline Chaetodontidae & Chaetodon striatus & 1 & IS & $12.4^{\mathrm{c}}$ \\
\hline Ephippidae & Chaetodipterus faber & 1 & IM & $9.4^{\mathrm{c}}$ \\
\hline Acanthuridae & Acanthurus chirurgus & 1 & RH & $14.0^{\mathrm{c}}$ \\
\hline
\end{tabular}

in the Reef zone. Adults of Lutjanus jocu only occurred at the Transition zone. The only species found exclusively at the transition zone, Thalassophryne nattereri, is in fact a typically estuarine species and was also sighted at Tanques sub-area, off the area covered by transects.

The Reef zone exhibited the most abundant and diverse fish assemblage, including 25 species, 12 of which exclusively found there: Acanthurus chirurgus, A. coeruleus, Anisotremus virginicus, Chaetodon striatus, Coryphopterus glaucofraenum, Haemulon parra, Ocyurus chrysurus, Pareques acuminatus, Scarus sp., Sparisoma sp., Stegastes fuscus, and Trachinotus falcatus. The most abundant species in the reefs were Abudefduf saxatilis, Anisotremus surinamensis, and Sparisoma sp., represented by juveniles and adult specimens. The two latter species were also recorded at the Estuarine and Transition zones, throughout the year, but with higher abundances recorded from March to August (rainy season) at the study site. Stegastes spp. (adults and juveniles) and Coryphopterus glaucofraenum (adults) were typically Reef zone species, with Stegastes variabilis also occurring at the Transition zone.

Our data revealed two interconnected fish assemblages, composed of estuarine and reef fishes. Along the mangrove-reef gradient, several estuarine species appear to be gradually replaced by reef species. Additionally, size distribution of several species tend to differ between the estuarine zone and the transition and/or reef zone, with smaller individuals concentrating at the former and larger individuals at the latter zones. This type of distribution is exemplified by Abudefduf saxatilis, Anisotremus surinamensis, Lutjanus alexandrei, and L. jocu (Fig. 2). 
Table 3. Species abundance (N), population density (Dens.) as individuals per $100 \mathrm{~m}^{2}$ and size (mean ${ }^{ \pm}$standard deviation) of fishes sighted at the Mamanguape Mangrove-Reef system, State of Paraíba, NE Brazil, according to each sub-area during the dry season (October 2007 to February 2008, and September 2008). ? = undetermined values.

\begin{tabular}{|c|c|c|c|c|c|c|c|c|c|c|c|c|c|c|c|}
\hline \multirow[t]{2}{*}{ Species } & \multicolumn{3}{|c|}{ Tanques } & \multicolumn{3}{|c|}{ Peixe-Boi } & \multicolumn{3}{|c|}{ Cação } & \multicolumn{3}{|c|}{ Transition } & \multicolumn{3}{|c|}{ Reefs } \\
\hline & $\mathrm{N}$ & Dens. & Size $(\mathrm{cm})$ & $\mathrm{N}$ & Dens. & Size $(\mathrm{cm})$ & $\mathrm{N}$ & Dens. & Size $(\mathrm{cm})$ & $\mathrm{N}$ & Dens. & Size $(\mathrm{cm})$ & $\mathrm{N}$ & Dens. & Size $(\mathrm{cm})$ \\
\hline Abudefduf saxatilis & 1 & 0.034 & $3.0 \pm 0$ & - & - & - & - & - & - & - & - & - & 8 & 0.888 & $3.8 \pm 2.47$ \\
\hline Acanthurus bahianus & 2 & 0.069 & $6.5 \pm 4.95$ & - & - & - & - & - & - & - & - & - & - & - & - \\
\hline Acanthurus chirurgus & - & - & - & - & - & - & - & - & - & - & - & - & - & - & - \\
\hline Acanthurus coeruleus & - & - & - & - & - & - & - & - & - & - & - & - & - & - & - \\
\hline Achirus lineatus & 4 & 0.138 & $16.2 \pm 4.79$ & - & - & - & - & - & - & 1 & 0.066 & $10.0 \pm 0$ & - & - & - \\
\hline Anisotremus surinamensis & - & - & - & - & - & - & - & - & - & 2 & 0.133 & $2.0 \pm 0$ & 8 & 0.888 & $9.1 \pm 2.47$ \\
\hline Anisotremus virginicus & - & - & - & - & - & - & - & - & - & - & - & - & 1 & 0.111 & $7.0 \pm 0$ \\
\hline Bathygobius soporator & 4 & 0.138 & $5.5 \pm 1.00$ & 7 & 0.269 & $6.3 \pm 2.56$ & - & - & - & 1 & 0.066 & $10.0 \pm 0$ & 1 & 0.111 & $3.0 \pm 0$ \\
\hline Centropomus sp. & 4 & 0.276 & $8.3 \pm 2.32$ & 4 & 0.154 & $10.0 \pm 0$ & - & - & - & - & - & - & - & - & - \\
\hline Chaetodipterus faber & 1 & 0.034 & $10.0 \pm 0$ & - & - & - & - & - & - & - & - & - & - & - & - \\
\hline Chaetodon striatus & - & - & - & - & - & - & - & - & - & - & - & - & 1 & 0.111 & $5.0 \pm 0$ \\
\hline Citharichthys spilopterus & - & - & - & - & - & - & - & - & - & 1 & 0.066 & $5.0 \pm 0$ & & & \\
\hline Coryphopterus glaucofraenum & - & - & - & - & - & - & - & - & - & - & - & - & 3 & 0.333 & $4.3 \pm 1.15$ \\
\hline Dactylopterus volitans & 2 & 0.069 & $12.5 \pm 3.53$ & 2 & 0.076 & $22.5 \pm 10.6$ & - & - & - & - & - & - & - & - & - \\
\hline Dasyatis guttata & 1 & 0.034 & $?$ & - & - & - & - & - & - & - & - & - & - & - & - \\
\hline Echeneis naucrates & 1 & 0.034 & $6.0 \pm 0$ & - & - & - & - & - & - & 1 & 0.066 & $20.0 \pm 0$ & - & - & - \\
\hline Epinephelus adscensionis & - & - & - & 1 & 0.038 & $30.0 \pm 0$ & - & - & - & 2 & 0.133 & $10.0 \pm 0$ & - & - & - \\
\hline Eucinostomus melanopterus & 3 & 0.103 & $5.0 \pm 0$ & 11 & 0.423 & $5.9 \pm 5.16$ & 1 & 0.143 & 10.0 & - & - & - & - & - & - \\
\hline Haemulon parra & - & - & - & - & - & - & - & - & - & 5 & 0.333 & $4.0 \pm 0.7$ & 1 & 0.111 & $10.0 \pm 0$ \\
\hline Hippocampus reidi & 4 & 0.138 & $7.2 \pm 3.86$ & 3 & 0.115 & $13.6 \pm 0.58$ & - & - & - & 1 & 0.066 & $9.0 \pm 0$ & - & - & - \\
\hline Lutjanus alexandrei & 8 & 0.276 & $8.7 \pm 2.31$ & 20 & 0.769 & $10.0 \pm 3.62$ & - & - & - & - & - & - & - & - & - \\
\hline Lutjanus analis & 2 & 0.069 & $5 \pm 0$ & 4 & 0.154 & $8.7 \pm 2.50$ & - & - & - & 1 & 0.067 & $3.0 \pm 0$ & 8 & 0.889 & $3.8^{ \pm} 2.47$ \\
\hline Lutjanus jocu & - & - & - & 8 & 0.308 & $7.75 \pm 3.01$ & - & - & - & 15 & 1.000 & $22.0 \pm 8.41$ & - & - & - \\
\hline Microphis brachyurus & 1 & 0.034 & $10.0 \pm 0$ & - & - & - & - & - & - & - & - & - & - & - & - \\
\hline Mugil sp. & - & - & - & - & - & - & - & - & - & - & - & - & - & - & - \\
\hline Myrichthys ocellatus & 1 & 0.034 & $?$ & - & - & - & - & - & - & - & - & - & - & - & - \\
\hline Ocyurus chrysurus & - & - & - & - & - & - & - & - & - & - & - & - & - & - & - \\
\hline Ophichthus ophis & 1 & 0.034 & $?$ & - & - & - & - & - & - & - & - & - & - & - & - \\
\hline Pareques acuminatus & - & - & - & - & - & - & - & - & - & - & - & - & - & - & - \\
\hline Rypticus randalli & 6 & 0.207 & $10.0 \pm 0$ & 2 & 0.077 & $10.0 \pm 0$ & & - & - & 5 & 0.333 & $10.0 \pm 0$ & - & - & - \\
\hline Scarus sp. & - & - & - & - & - & - & - & - & - & - & - & - & - & - & - \\
\hline Sparisoma sp. & - & - & - & - & - & - & - & - & - & - & - & - & - & - & - \\
\hline Sphoeroides testudineus & 3 & 0.103 & $8.3 \pm 5.77$ & - & - & - & - & - & - & 1 & 0.067 & $5.0 \pm 0$ & - & - & - \\
\hline Stegastes fuscus & - & - & - & - & - & - & - & - & - & - & - & - & 1 & 0.111 & $5.0 \pm 0$ \\
\hline Stegastes variabilis & - & - & - & - & - & - & - & - & - & 2 & 0.133 & $10.0 \pm 0$ & 1 & 0.111 & $5.0 \pm 0$ \\
\hline Thalassophryne nattereri & - & - & - & - & - & - & - & - & - & - & - & - & - & - & - \\
\hline Trachinotus falcatus & - & - & - & - & - & - & - & - & - & - & - & - & - & - & - \\
\hline
\end{tabular}

Trophic groups. Overall, the predominant trophic categories were mobile invertivores, represented by 15 species and carnivores, by 11 species (see Table 2). Considering the Estuarine zone, the most abundant groups were carnivores (55.5\% of total abundance), mainly represented by the genus Lutjanus, and invertivores of mobile prey (42.1\%), mostly represented by Bathygobius soporator and Eucinostomus melanopterus. Transition zone exhibited a higher abundance of invertivores of mobile prey (69.7\%), largely represented by Anisotremus surinamensis and Eucinostomus melanopterus. Omnivores were the second most abundant group at the Transition zone (11.8\%), and were solely represented by juveniles of Abudefduf saxatilis. The Reef zone showed the highest abundance of omnivores (50.1\%), mainly Abudefduf saxatilis, followed by invertivores of mobile prey (31\%), mostly represented by Anisotremus surinamensis.

The Reef zone exhibited a low abundance of carnivores $(2.3 \%)$. Instead, it was characterized by a high abundance of herbivores $(16.3 \%)$, a trophic group either poorly or not represented in the remaining sub-areas (Tanques: 3.4\%;
Transition: 2.2\%; Peixe-Boi and Cação lacking herbivores). Herbivore species included roving herbivores such as Acanthurus sp. and Sparisoma sp., and territorial herbivores, represented by Stegastes fuscus and S. variabilis.

Canonical Correspondence Analysis (CCA), as performed in the first plot (Fig. 3a), identified mangroves, rocky structures, sessile invertebrates and bivalve shells, as important environmental variables structuring the fish assemblages. The following species were associated to the mangrove structures and hence to the Estuarine zone: $A$. bahianus, B. soporator, Centropomus sp., D. volitans, Lutjanus spp., H. reidi, $R$. randalli, and S. testudineus; associated to bivalves, rocky structures and sessile invertebrates, predominant on the Reef zone: A. saxatilis, $A$. coeruleus, A. bahianus, A. surinamensis, A. virginicus, $C$. glaucofraenum, E. adscensionis, S. fuscus, S.variabilis, Scarus sp., and Sparisoma sp.; and associated to seagrass and algae vectors, encompassing species that predominated on the Transition zone: A. lineatus, C. spilopterus, E. naucrates, and E. melanopterus. A second CCA was 
Table 4.Species abundance (N), population density (Dens.) as individuals per $100 \mathrm{~m}^{2}$ and size (mean ${ }^{ \pm}$standard deviation) of fishes sighted at the Mamanguape Mangrove-Reef System, State of Paraíba, NE Brazil, according to each sub-area during the rainy season (March to August 2008).

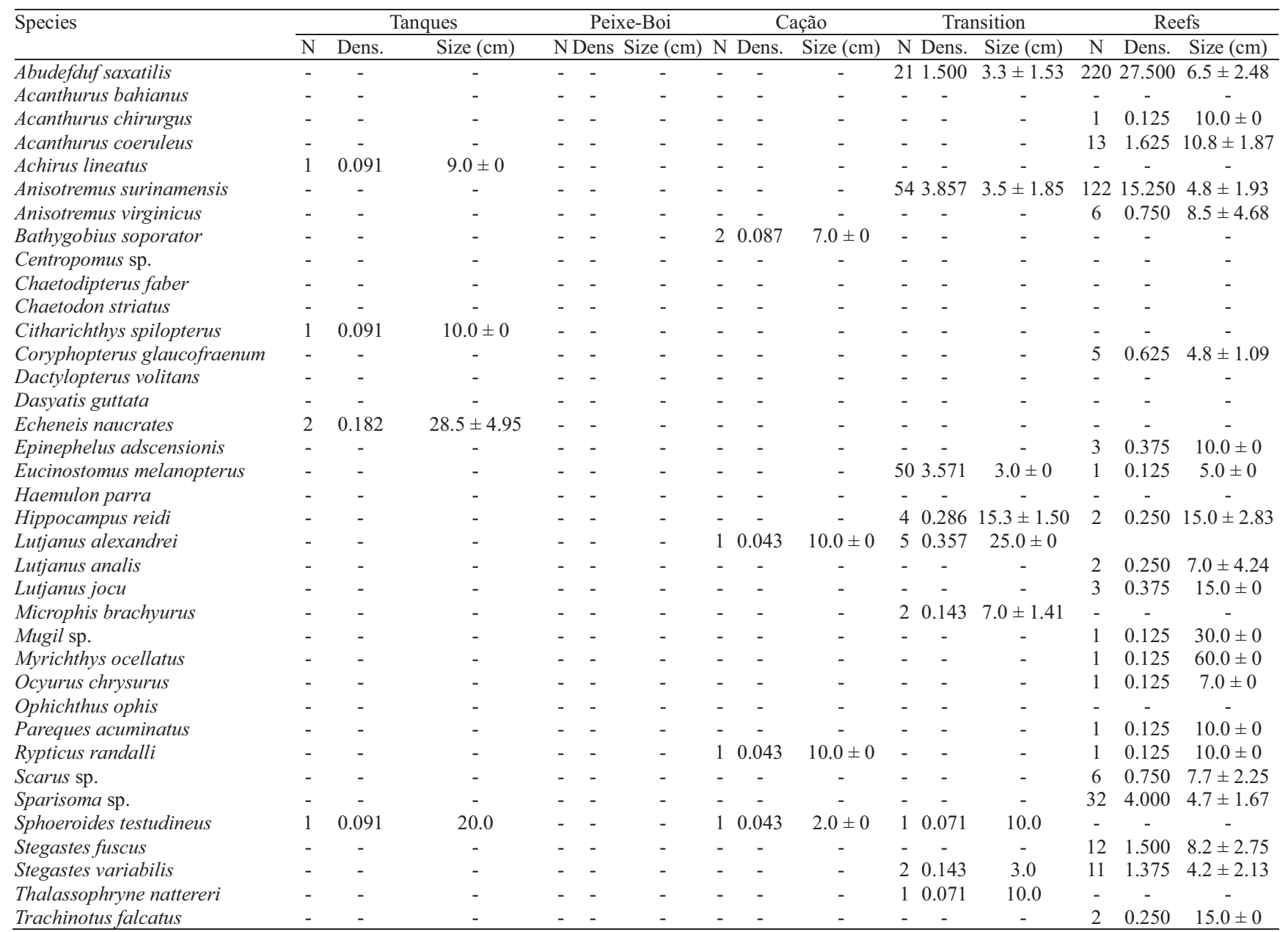

performed with mangroves, rocky structures and salinity as the most important environmental variables (vectors), while trophic groups and sub-areas were represented by symbols distributed across environmental ranges. As shown in Fig. $3 \mathrm{~b}$, roving and territorial herbivores, as well as omnivores, are clearly associated to the rocky structures, while carnivores remained associated to mangroves. Invertivores of mobile prey were unrelated to any specific variable.

\section{Discussion}

Fish composition and spatial distribution. The spatial distribution of fishes may be related to several factors, including the distribution of prey, habitat availability or the physiological capabilities of individual species relative to environmental conditions (Williams, 1991). In Northeast Brazil, Andrade-Tubino et al. (2008) estimated that about 51\% of estuarine species (mainly represented by families Haemulidae and Lutjanidae) are opportunists, while Osório et al. (2011) considered all sighted fish species at the Pacoti estuary (NE
Brazil) as originally marine, which might enter the estuary for feeding, shelter and nursery. The following species, considered as opportunists (Andrade-Tubino et al., 2008), were sighted in our study: Anisotremus surinamensis, Citharichthys spilopterus, Datylopterus volitans, Gymnothorax funebris, Haemulon parra, Hippocampus reidi, Lutjanus sp., Ocyurus chrysurus, Rypticus randalli, Sparisoma sp., Sphoeroides testudineus, and Strongylura sp., comprising $34.1 \%$ of all sighted fish species at the Mamanguape estuary.

Fish assemblage along the Mamanguape Mangrove-Reef system was strongly related to the microhabitat availability, as revealed by the representative numbers of carnivores at the Estuarine zone and herbivores at the Reef zone. This result agrees with those obtained in the Indo-Pacific by Unsworth et al. (2009), who found that carnivorous fishes were the predominant feeding group in the mangroves, while omnivores dominated on the mangrove edge and seagrass beds, and a representative number of herbivores were present on adjacent coral reefs. 
Table 5. Percentage of substrate cover (main items), rugosity index and salinity (mean ${ }^{ \pm}$standard deviation and variation) along the Mamanguape Mangrove-Reef system, Paraíba, NE Brazil, according to the sampling sub-areas from October 2007 to September 2008. *. Cover categories: S/M - sandy or muddy bottom, without visually detectable organisms; Ma - Mangrove roots, leaves and fallen branches of mangrove trees, mainly Rhizophora mangle; Sg - Seagrass beds, Halophila sp. and Halodule wrightii; Bv - bivalve shells, mainly Crassostrea rhizophorae, Anomalocardia brasiliana, and Lucina pectinata; $\mathrm{Si}$ - Sessile invertebrates, sponges, including Haliclona sp., Cinachyrella alloclada, and cnidarians, including Carijoa sp.; $\mathrm{Mb}$ - Macroalgae beds, red algal beds, mainly composed by Hypnea musciformis, Hypnea spinella, Cryptonemia sp., and Acanthophora sp.; Oa - Other algae, drifting or attached algae (not forming beds), which included Gracilaria sp., Gelidiella acerosa, Pterocladia sp., Gelidium sp., Corynomorpha sp., and Acetabularia sp.

\begin{tabular}{|c|c|c|c|c|c|c|c|c|c|}
\hline \multirow[b]{2}{*}{ Sub-area } & \multicolumn{7}{|c|}{ Percentage of substrate cover categories* } & \multirow[b]{2}{*}{ Rugosity } & \multirow[b]{2}{*}{ Mean salinity } \\
\hline & $\mathrm{S} / \mathrm{M}$ & Ma & $\mathrm{Sg}$ & $\mathrm{Bv}$ & $\mathrm{Si}$ & $\mathrm{Mb}$ & $\mathrm{Oa}$ & & \\
\hline 1 Tanques & 71.5 & 9.2 & 8.3 & 7.1 & 0.1 & 1.4 & 2.4 & 0.11 & $31.3 \pm 4.9(20-43)$ \\
\hline 2 Peixe-Boi & 83.1 & 10.3 & 2.9 & 2.2 & 0.1 & 0.2 & 1.2 & 0.11 & $34.0 \pm 5.0(20-43)$ \\
\hline 3 Cação & 84.7 & 3.1 & 0.0 & 10.9 & 0.2 & 0.0 & 1.1 & 0.11 & $31.3 \pm 4.5(24-39)$ \\
\hline 4 Transition & 85.4 & 3.3 & 2.6 & 1.9 & 3.0 & 2.2 & 1.6 & 0.12 & $36.6^{ \pm} 1.8(35-40)$ \\
\hline 5 Reefs & 56.6 & 0.5 & 0.9 & 0.4 & 2.9 & 31.9 & 6.8 & 1.13 & $36.9 \pm 3.1(31-41)$ \\
\hline
\end{tabular}

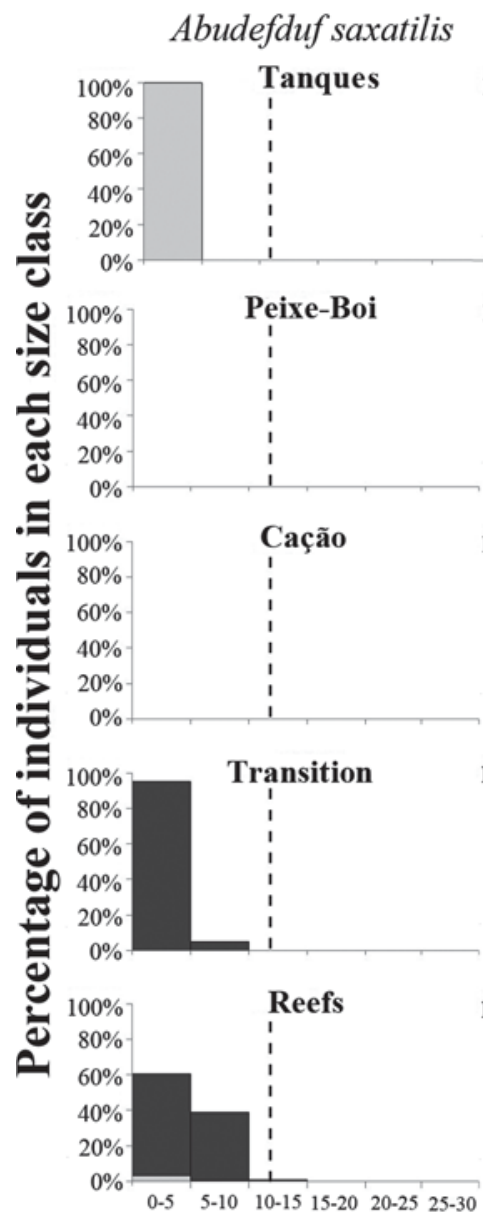

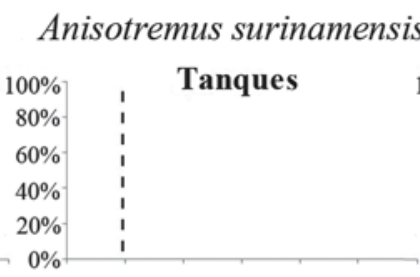
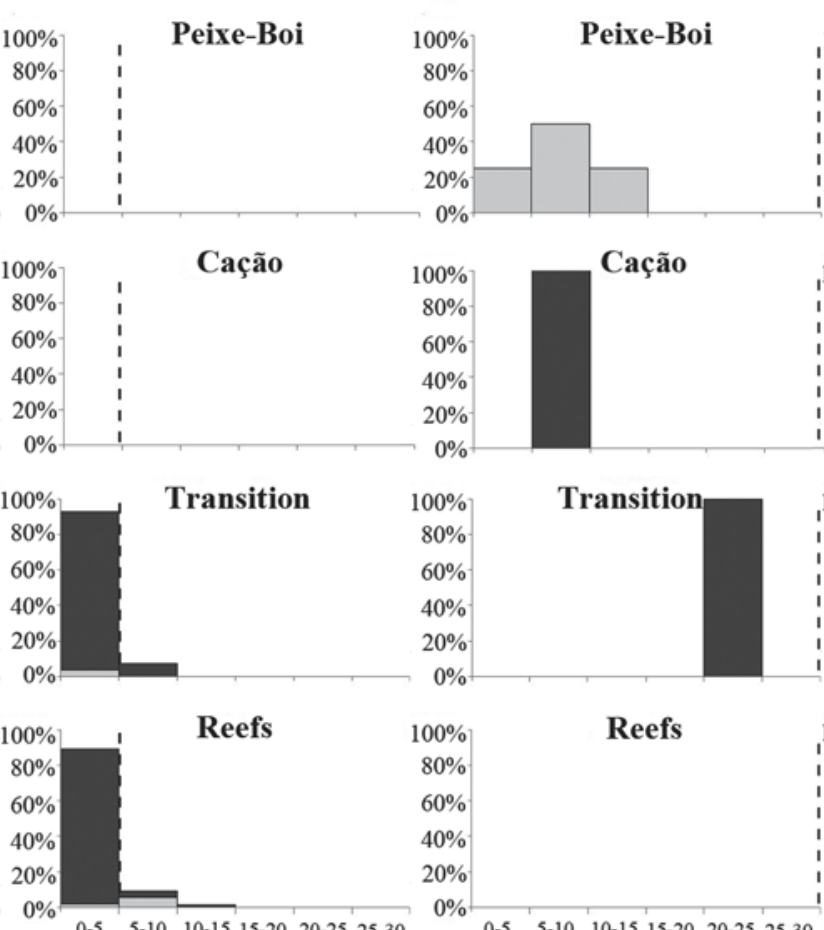

Size class $(\mathbf{c m})$

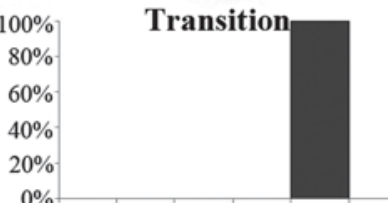

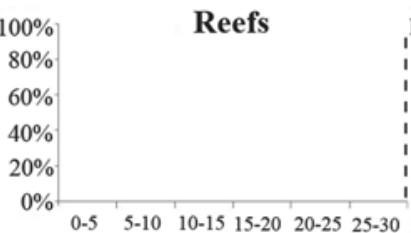

Lutjanus alexandrei

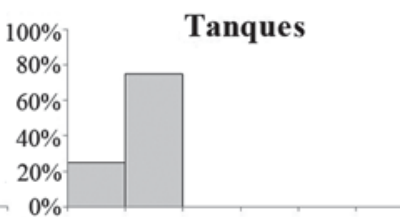

Lutjanus jocu

Tanques

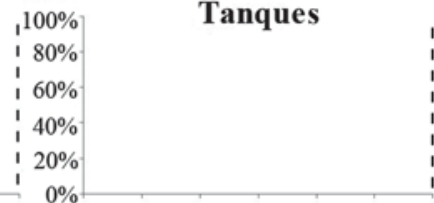

Peixe-Boi
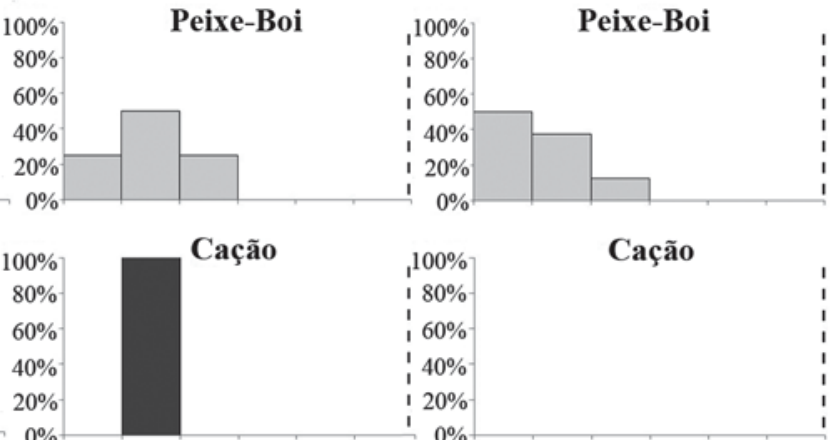

$100 \% 7$ Cação

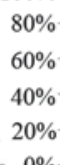

$100 \% \quad$ Transition

$60 \%$

$40 \%$

$20 \%$
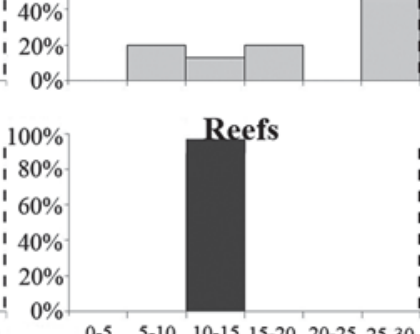

$\square$ Dry season $\square$ Rainy season

Fig. 2. Ontogenetic patterns of habitat use in Abudefduf saxatilis, Anisotremus surinamensis, Lutjanus alexandrei, and L. jocu along the sub-areas of Mamanguape Mangrove-Reef system, NE Brazil, showing an increase in individual size classes from the Estuarine to the Reef zone. Mann Whitney U Test showed significant size differences between all sub-areas (for A. saxatilis, Transition vs. Reefs: $\mathrm{U}=491, \mathrm{Z}=-6.02, \mathrm{p}=0.00$; for A. surinamensis, Transition $v s$. Reefs: $\mathrm{U}=1338, \mathrm{Z}=-6.83$, $\mathrm{p}=0.00$; for L. alexandrei, Peixe-Boi vs. Transition: $\mathrm{U}=0.00, \mathrm{Z}=-3.39, \mathrm{p}=0.00$; and Tanques $v s$. Transition: $\mathrm{U}=0.00, \mathrm{Z}=$ -2.92, $\mathrm{p}=0.00$; for $L$. jocu, Peixe-Boi vs. Transition: $U=7.5, Z=-3.38, p=0.00$ ), except between Tanques and Peixe-Boi for L. alexandrei $(\mathrm{U}=65, \mathrm{Z}=0.76, \mathrm{p}=0.46)$. 
The abundance of Carnivores at the Estuarine zone was probably related to the high abundance of young from a variety of taxa in that area, a result in line with Ogden \& Gladfelder (1983), who remarked that those organisms and their relative vulnerability during migrations attract carnivorous fish to mangroves from surrounding systems, such as coral reefs.

The species Lutjanus alexandrei, L. jocu, and Bathygobius soporator were the most representative, in terms of abundance and frequency of occurrence, along the estuarine margins, inhabiting mangrove roots and other complex structures at the Estuarine zone. Osório et al. (2011) also considered these species as representative of the mangrove ecosystem, and their presence appear to be a typical feature of mangrove areas in NE Brazil.

Herbivore fishes are known to compose the bulk of fish biomass on coral reefs, where they play a vital role transferring energy from the base to the top of the food web (Horn, 1989; Choat, 1991). Although less diverse than other trophic groups, their huge biomass exerts a strong influence on the abundance of the epilithic algae community and on sediment transport (Bruggemann, 1994; Bellwood, 1995). Considering the high abundance of macroalgal beds and herbivore fishes in the Reef zone, we can assume that they play an important role on the trophic balance in the area, based on the availability of space, nutrients, and luminosity (see Francini-Filho et al., 2010).

Herbivore species recorded in this study (Acanthurus sp., Stegastes sp., Sparisoma sp., Scarus sp.) are conspicuous along the Brazilian coast (Ferreira et al., 2004; Floeter et al., 2005) and abundant in northeastern Brazilian reefs (Rocha et al., 1998; Medeiros et al., 2007; Ilarri et al., 2008; FranciniFilho et al., 2010). Scarids, represented in our study by Scarus sp. and Sparisoma sp., are known for their feeding plasticity (Bonaldo et al., 2006) which makes them very adaptable to feeding on different sources. Acanthurids are known to tolerate low salinity (Rocha et al., 2002) and thus to explore estuarine habitats, as occurred with Acanthurus bahianus in our study. The other species of surgeonfishes (A. chirurgus and $A$. coeruleus) were only sighted at the Reef zone.
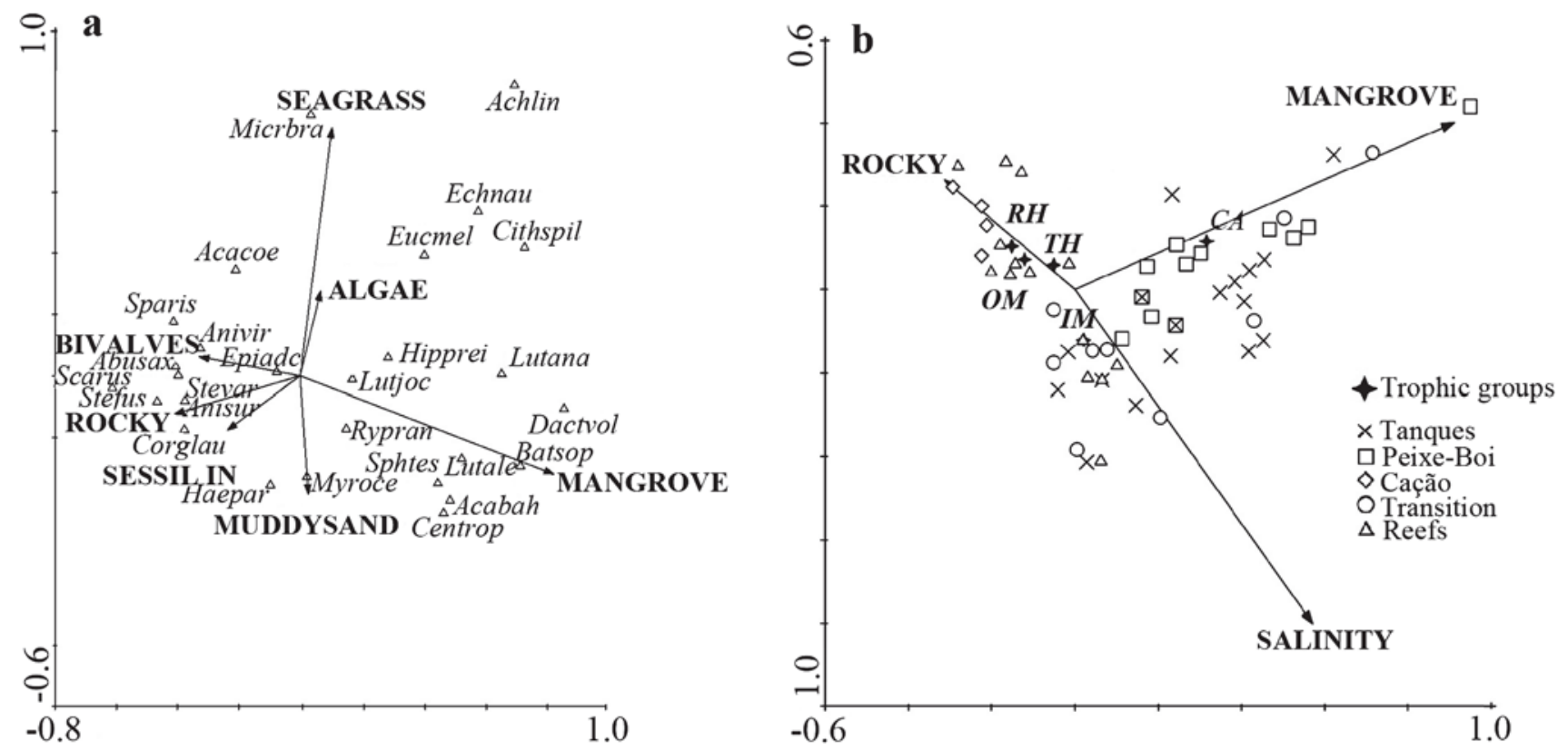

Fig. 3. Canonical Correspondence Analysis of fishes and environmental parameters from Mamanguape Mangrove-Reef system, NE Brazil: (a) fish species (symbols) in relation to microhabitat categories (vectors) - Eigenvalues: axis 1, 0.56; axis 2, 0,20; $r$ species-environment: axis 1, 0.87; axis 2, 0.56; First two axes accounted for $64.9 \%$ of the variance; (b) fish trophic groups and subareas (symbols) in relation to environmental categories (vectors) - Eigenvalues: axis 1, 0.49; axis 2, 0.39; r species-environment: axis 1, 0.79; axis 2, 0.76; First two axes accounted for 51.6\% of the variance. Monte-Carlo test of all canonical axes were significant $(p<0.01), 999$ permutations. Abbreviations as follows - fish species: Abusax: Abudefduf saxatilis; Acabah: Acanthurus bahianus; Acacoe: A. coeruleus; Achlin: Achirus lineatus; Anisur: Anisotremus surinamensis; Anivir: A. virginicus; Batsop: Bathygobius soporator; Centrop: Centropomus sp.; Cithspil - Citharichthys spilopterus; Corglau - Coryphopterus glaucofraenum; Dactvol - Dactylopterus volitans; Echnau: Echeneis naucrates; Epiadc: Epinephelus adscensionis; Eucmel: Eucinostomus melanopterus; Haepar: Haemulon parra; Hipprei: Hippocampus reidi; Lutana: Lutjanus analis; Lutale: L. alexandrei; Lutjoc: L. jocu; Micrbra: Microphis brachyurus; Myroce: Myrichthys ocellatus; Rypran: Rypticus randalli; Scarus: Scarus sp.; Sparis: Sparisoma sp.; Sphtes: Sphoeroides testudineus; Stefus: Stegastes fuscus; Stevar: S. variabilis; trophic groups: RH Roving herbivore; TH - Territorial herbivore; OM - Omnivore; CA - Carnivore; IM - Invertivore of mobile prey. 
Finally, the genus Stegastes, represented here by S. fuscus and $S$. variabilis, seem to be very dependent on the reef matrix and site-attached due to their farming habits (Ferreira et al., 1998; Barneche et al., 2009); nevertheless, representatives of that genus can inhabit brackish waters, as exemplified by S. otophorus (Froese \& Pauly, 2010) and by Stegastes variabilis in this study.

Among the fishes found on our surveys, Mugil sp., $C$. spilopterus, L. jocu, and E. melanopterus are typically found in estuaries at Northeastern Brazil (Andrade-Tubino et al., 2008). On the Reef zone, Stegastes fuscus, S. variabilis, Acanthurus sp., Chaetodon striatus, Pareques acuminatus, scarids and haemulids, encompass a vast assemblage of fishes found on Brazilian reefs, being generally associated to habitat complexity, reef topography and cover of benthic organisms (Rosa et al., 1997; Ferreira et al., 2001; Ferreira et al., 2004; Floeter et al., 2007).

The abundance and diversity of fishes in the Reef zone, as well as the concentration of fishes along the margins of the estuary, highlighted the importance of structural complexity (in our study, rugosity), which was higher in those habitats. A higher abundance of fishes, and also the higher population densities of the seahorse Hippocampus reidi, possibly are related (among other aspects) to this greater habitat complexity. The role played by high structural complexity in providing food, shelter, refuge from predators and settlement places for pelagic fish larvae has been highlighted in various studies (e.g., Ferreira et al., 2001; Gratwicke \& Speight, 2005), while the structural complexity resulting from mangrove roots, debris, and other vegetation structures of the intertidal habitat has been shown to enhance the refuge aspect of habitats (Rönnbäck, 1999; Weis \& Weis, 2005; Osório et al., 2011).

Ecosystem connectivity: species along the mangrove-reef gradient. Connectivity studies between mangrove and reef ecosystems are often complicated by differences in geomorphology and tidal range of estuaries (Barletta et al., 2003) and by local variations of environmental factors such as hydrodynamics, depth, shading and prop-root densities (Nagelkerken \& Faunce, 2007). These local variations may determine the mangrove's fish composition and strongly influence the fish community structure on neighboring reefs (Mumby et al., 2004; Nagelkerken \& Faunce, 2007). Therefore, connectivity studies of these ecosystems should not be limited to the comparison of shared species, but instead should look at physical processes of connectivity along the ecotones and to assess information on functional groups of fishes (Nagelkerken \& Faunce, 2007).

In spite of the limited number of physical factors investigated, our results on fish assemblage composition, microhabitat use and functional groups suggest connectivity among mangrove, seagrass, and reef biotopes in the study area. Results also revealed that the fish composition along the study area gradually changed from the Estuarine to the Reef zone, despite the fact that these biotopes were distant only a few kilometers from each other. Such change is possibly related to complex interactions of multiple factors, including some that were not assessed in this study. Differences in salinity, turbidity, organic matter, and bottom structure, for example, are variables known to play a role in the structure of fish assemblages in the estuarine environments (see Barletta et al., 2005).

In our study, we highlight the high abundance of mangrove-associated structures, oysters, and seagrass which predominated on the muddy and sandy bottom of the Estuarine zone, and were gradually replaced by the beds of macroalgae and sessile invertebrates (sponges and cnidarians) found on the sandy and rocky substrate of the Reef zone, possibly exerting a significant effect on the structure of the fish assemblage. Additionally, this gradual change in bottom structure may play a role in ontogenetic habitats shifts at the study site. As discussed by Gratwicke et al. (2006), the fact that some species appear to have incremental ontogenetic transitions from habitat type to habitat type means that sh assemblage composition may depend not only on the type of habitat available, but on the contiguity and dispersion of adjacent habitat types.

Nursery role of the Mamanguape Mangrove-Reef System. Various authors have discussed the nursery potential of certain habitats, such as mangroves, seagrass beds and shallow coral reefs (Nagelkerken et al., 2000; Dorenbosch et al., 2004; Gratwicke et al., 2006; Mumby et al., 2008; Nagelkerken \& Faunce, 2008; Nagelkerken et al., 2008; Unsworth et al., 2009), an aspect highlighted in our study by the predominance of juveniles. Fishes at that life stage may benefit from the shelter provided by environmental characteristics observed in this study, such as shallow habitats, high turbidity, and soft mud suitable for burrowing, all as a result of the sediment-trapping capacity of mangroves (see Rönnbäck, 1999).

Nevertheless, even though connectivity between coral reefs and mangroves or seagrass beds can benet the reef fish fauna (i.e. food and shelter for juveniles, additional space and feeding resources for adults), generalizations about the nursery role of these habitats should be avoided. Not all mangrove or seagrass beds appear to offer nursery function, not all fish species use these services as well (Chittaro et al., 2005). As pointed out by Nagelkerken \& Faunce (2008), there is a need for a species-based approach towards assessing the benets provided by nursery habitats for fishes.

Our results revealed the presence of smaller individuals at the Estuarine zone and larger individuals at the Transition and/or Reef zone for Abudefduf saxatilis, Anisotremus surinamensis, Lutjanus alexandrei, and L. jocu, a typical pattern for species that use shift between contiguous habitats during ontogeny. Additionally, the Reef zone exhibited an abundant macroalgal cover, where juveniles of many herbivore species were found, suggesting that the reef may provide shelter (high turbidity) and food (algae beds) to juveniles.

It is possible that several other species may present this ontogenetic patterns of distribution along the study area - 
Table 6. Fishes recorded along the Mamanguape Mangrove-Reef system, State of Paraíba, NE Brazil, according to the zone where they occurred. Species that occurred in our study are marked with an asterisk.

\begin{tabular}{|c|c|c|}
\hline \multicolumn{3}{|c|}{ Estuarine species - those exclusively found on the Estuarine zone (sources: Rosa \& Sassi, 2002; this study) } \\
\hline Achirus declivis Chabanaud, 1940 & Cynoscion leiarchus (Cuvier, 1830) & Nebris microps Cuvier, 1830 \\
\hline Achirus lineatus (Linnaeus, 1758)* & Cynoscion microlepidotus (Cuvier, 1830) & Odontognathus mucronatus Lacepède, 1800 \\
\hline Albula vulpes (Linnaeus, 1758) & Dactylopterus volitans (Linnaeus, 1758)* & Oligoplites palometa (Cuvier, 1832) \\
\hline Anchoa januaria (Steindachner, 1879) & Dasyatis guttata (Bloch \& Schneider, 1801)* & Ophichthus cylindroideus (Ranzani, 1839) \\
\hline Anchoa tricolor (Spix \& Agassiz, 1829) & Diapterus auratus Ranzani, 1842 & Ophichthus ophis (Linnaeus, 1758)* \\
\hline Anchovia clupeoides (Swainson, 1839) & Diapterus rhombeus (Valenciennes, 1830) & Ophioscion punctatissimus Meek\&Hildebrand, 1925 \\
\hline Antennarius sp.* & Echeneis naucrates Linnaeus, $1758^{*}$ & Opisthonema oglinum (Lesueur, 1818) \\
\hline Archosargus rhomboidalis (Linnaeus, 1758) & Eleotris pisonis (Gmelin, 1789) & Paralonchurus brasiliensis (Steindachner, 1875) \\
\hline Arius herzbergii (Bloch, 1794) & Elops saurus Linnaeus, 1766 & Pellona harroweri (Fowler, 1919) \\
\hline Arius proops (Valenciennes, 1840) & Eucinostomus argenteus Baird \& Girard, 1855 & Peprilus paru (Linnaeus, 1758) \\
\hline Arius quadriscutis (Valenciennes, 1840) & Eugerres brasilianus (Valenciennes, 1830) & Polydactylus virginicus (Linnaeus, 1758) \\
\hline Atherinella brasiliensis (Quoy \& Gaimard, 1824) & Gobionellus boleosoma (Jordan \& Gilbert, 1882) & Pomadasys corvinaeformis (Steindachner, 1868) \\
\hline Bagre marinus (Mitchill, 1815) & Gobionellus oceanicus (Pallas, 1770) & Prionotus punctatus (Bloch, 1793) \\
\hline Bairdiella ronchus (Cuvier, 1830) & Gobionellus smaragdus (Valenciennes, 1837) & Rachycentron canadus (Linnaeus, 1766) \\
\hline Bothus ocellatus (Agassiz, 1831) & Gymnothorax ocellatus Agassiz, 1831 & Rhinosardinia amazonica (Steindachner, 1879) \\
\hline Caranx latus Agassiz, 1831 & Gymnura micrura (Bloch \& Schneider, 1801) & Sardinella brasiliensis (Steindachner, 1879) \\
\hline Cathorops spixii (Agassiz, 1829) & Haemulon steindachneri (Jordan \& Gilbert, 1882) & Scorpaena plumier Bloch, 1789 \\
\hline Centropomus ensiferus Poey, 1860 & Harengula clupeola (Cuvier, 1829) & Selene vomer (Linnaeus, 1758) \\
\hline Centropomus mexicanus Bocourt, 1868 & Hemiramphus brasiliensis (Linnaeus, 1758) & Serranus flaviventris (Cuvier, 1829) \\
\hline Centropomus pectinatus Poey 1860 & Hyporhamphus unifasciatus (Ranzani, 1842) & Sphoeroides greeley Gilbert, 1900* \\
\hline Centropomus undecimalis (Bloch, 1796)* & Lagocephalus laevigatus Linnaeus, 1766 & Stellifer brasiliensis (Schultz, 1945) \\
\hline Cetengraulis edentulus (Cuvier, 1829) & Larimus breviceps Cuvier, 1830 & Stellifer rastrifer (Jordan, 1889) \\
\hline Chaetodipterus faber (Broussonet, 1782)* & Lutjanus cyanopterus (Cuvier, 1828) & Strongylura timuси (Walbaum, 1792)* \\
\hline Chilomycterus antillarum Jordan \& Rutter, 1897 & Lycengraulis grossidens (Agassiz, 1829) & Symphurus tesselatus (Quoy \& Gaimard, 1824) \\
\hline Chloroscombrus chrysurus (Linnaeus, 1766) & Menticirrhus americanus (Linnaeus, 1758) & Thalassophryne punctata Steindachner, 1876 \\
\hline Citharichthys arenaceus Evermann \& Marsh, 1900 & Menticirrhus littoralis (Holbrook, 1847) & Trachinotus carolinus (Linnaeus, 1766) \\
\hline Citharichthys spilopterus Günther, 1862* & Microphis brachyurus (Bleeker, 1853)* & Trachinotus goodei Jordan \& Evermann, 1896 \\
\hline Colomesus psittacus (Bloch \& Schneider, 1801) & Micropogonias furnieri (Desmarest, 1823) & Trinectes microphthalmus (Chabanaud, 1928) \\
\hline Conodon nobilis (Linnaeus, 1758) & Mugil curvidens Valenciennes, 1836 & Trinectes paulistanus (Miranda Ribeiro, 1915) \\
\hline Cynoscion acoupa (Lacepède, 1801) & Mugil gaimardianus Desmarest, 1831 & \\
\hline \multicolumn{3}{|c|}{ Transient species - those found in both Estuarine and Reef portions (sources: Rosa \& Sassi, 2002; Silva, 2002; this study) } \\
\hline Abudefduf saxatilis (Linnaeus, 1758)* & Gymnothorax vicinus (Castelnau, 1855) & Megalops atlanticus Valenciennes, 1847 \\
\hline Acanthurus bahianus Castelnau, $1855^{*}$ & Haemulon parra (Desmarest, 1823)* & Mugil curema Valenciennes, $1836^{*}$ \\
\hline Anisotremus surinamensis (Bloch, 1791)* & Haemulon plumieri (Lacepède, 1802)* & Myrichthys ocellatus (Lesuer, 1825)* \\
\hline Bathygobius soporator (Valenciennes, 1837)* & Hippocampus reidi (Ginsburg, 1933)* & Rypticus randalli Courtenay, $1967^{*}$ \\
\hline Epinephelus adscensionis (Osbeck, 1765)* & Lutjanus jocu (Bloch \& Schnneider, 1801)* & Sphoeroides testudineus (Linnaeus, 1758) \\
\hline Eucinostomus melanopterus (Bleeker, 1863)* & Lutjanus alexandrei Moura \& Lindeman, 2007* & Trachinotus falcatus (Linnaeus, 1758)* \\
\hline Gymnothorax funebris (Ranzani, 1840) & Lutjanus analis (Cuvier, 1828)* & \\
\hline \multicolumn{3}{|c|}{ Reef species - those exclusively found on the Reef zone (sources: Silva, 2002; this study) } \\
\hline Acanthurus chirurgus (Bloch, 1787)* & Gobionellus shufeldti (Jordan \& Eigenmann, 1887) & Pareques acuminatus (Bloch\&Schneider, 1801)* \\
\hline Acanthurus coeruleus Bloch \& Schneider, 1801* & Gymnothorax moringa (Cuvier, 1829) & Pomacanthus paru (Bloch, 1787) \\
\hline Ahlia egmontis (Jordan, 1884) & Hypleurochilus pseudoaequipinnis Bath, 1994 & Scartella aff. cristata (Linnaeus, 1758) \\
\hline Anisotremus virginicus (Linnaeus, 1758)* & Labrisomus nuchipinnis (Quoy \& Gaimard, 1824) & Scarus sp.* \\
\hline Cephalopholis fulva (Linnaeus, 1758) & Malacoctenus delalandii (Valenciennes, 1836) & Sparisoma sp.* \\
\hline Chaetodon striatus Linnaeus, 1758* & Nicholsina usta (Valenciennes, 1840) & Stegastes fuscus (Cuvier, 1830)* \\
\hline Coryphopterus glaucofraenum Gill, 1863* & Ocyurus chrysurus (Bloch, 1971)* & Stegastes variabilis (Castelnau, 1855)* \\
\hline Entomacrodus vomerinus (Valenciennes, 1836) & Parablennius aff. pilicornis (Cuvier, 1829) & \\
\hline
\end{tabular}

previous studies have recorded this pattern for Acanthurus chirurgus (Nagelkerken et al., 2000; Nagelkerken \& Faunce, 2008), Lutjanus alexandrei (Nagelkerken et al., 2000; Chittaro et al., 2005; Unsworth et al., 2009), Sparisoma viride (Nagelkerken et al., 2000) and S. chrysopterum (Nagelkerken \& Faunce, 2008), which used mangroves or seagrass beds as nursery biotopes; and also Abudefduf saxatilis and Acanthurus bahianus, which used shallow reef habitats as nurseries (Nagelkerken et al., 2000).

Estuarine vs. Reef fish communities. When combining our data from Estuarine and Reef zones with those sampling data obtained by Silva (2002) and Rosa \& Sassi (2002), it was possible to categorize the fish assemblage of the Mamanguape Mangrove-Reef System into three groups, as shown on Table
6: (1) Estuarine species, the group of species that emerged as typically estuarine; (2) Transient species, those found in both estuarine, transition and reef portions of the study area; and (3) Reef species, those exclusively found on the Reef zone.

It should be noted that the spatial distribution of the many fish species recorded in this study was well-known by local artisanal fishers, who applied several criteria for classifying fish, mostly based on behavior and habitat use (Mourão \& Nordi, 2003, 2006). For instance, they associated Thalassophryne nattereri and the flatfish Citharichthys spilopterus to the estuarine bottom (muddy substrate) and Bathygobius soporator to the mangrove roots and muddy habitats near that vegetation, in accordance to our study. In addition, fishermen referred to the Reef zone as the area with highest diversity of fishes (Mourão \& Nordi, 2006). 
Final remarks. The number of fish species recorded in our study clearly represents an underestimation of the total number of 103 species, previously reported for the area, based on a study using destructive sampling (Rosa \& Sassi, 2002), which surveyed additional habitats when compared to our study, including the upper sections of the estuary, deeper portions of the main channel and tide pools. Visual census techniques tend to underestimate cryptobenthic and highly mobile species (Ferreira et al., 2004). Nevertheless, underwater visual fish census can be a rapid and effective technique for gathering data and making quantitative comparisons of fish distribution, abundance, and size-structure within and among habitat types (Faunce \& Serafy, 2006).

The visual censuses performed in our study generated novel data relevant for management of the protected area located at the study site, such as fish associations with habitat features. Additionally, the taxa Antennarius sp., Sphoeroides greeleyi, Microphis brachyurus, Anisotremus virginicus, Chaetodon striatus, Ocyurus chrysurus, Pareques acuminatus, and Scarus sp. were recorded for the first time at the study site.

\section{Acknowledgements}

We thank to Coordenação de Aperfeiçoamento de Pessoal de Ensino Superior (CAPES) and Programa Institucional de Bolsas de Iniciação Científica (PIBIC), Universidade Federal da Paraíba (UFPB), for the scholarships provided. To Instituto Brasileiro de Meio Ambiente e dos Recursos Naturais Renováveis (IBAMA) for the research permits and support during field work. To Ismar Just and Mar Aberto Mergulhos, for the support with the dive gear. SSpecial thanks are due to Seu Arlindo and Gabriel Dantas, and also to the colleagues at the Laboratório de Peixes - Ecologia e Conservação (LAPEC). To NOAA (National Oceanic and Atmospheric Administration) that supports ongoing research at the study site, through the project "Promoting management of the APA da Barra do Rio Mamanguape watershed (NE Brazil)". To CNPq - Conselho Nacional de Desenvolvimento Científico e Tecnológico (grants 478486/2009 and 480026/2010-6), that supports ongoing studies of fish assemblages at marine protected areas in NE Brazil.

\section{Literature Cited}

Afonso, P., T. Morato \& R. S. Santos. 2008. Spatial patterns in reproductive traits of the temperate parrotfish Sparisoma cretense. Fisheries Research, 90: 92-99.

Andrade-Tubino, M. F., A. L. R. Ribeiro \& M. Vianna. 2008. Organização espaço-temporal das ictiocenoses demersais nos ecossistemas estuarinos brasileiros: uma síntese. Oecologia Brasiliensis, 12: 640-661.

Arrivillaga A. \& D. M. S. Baltz. 1999. Comparison of fishes and macroinvertebrates on seagrass and bare-sand sites on Guatemala's Atlantic Coast. Bulletin of Marine Science, 65: 301-319.

Barletta, M., A. Barletta-Bergan, U. Saint-Paul \& G. Hubold. 2003. Seasonal changes in density, biomass and diversity of estuarine fishes in tidal mangrove creeks of the lower Caeté estuary (northern Brazilian coast, east Amazon). Marine Ecology Progress Series, 256: 217-228.

Barletta, M., A. Barletta-Bergan, U. Saint-Paul \& G. Hubold. 2005. The role of salinity in structuring the fish assemblages in a tropical estuary. Journal of Fish Biology, 66:45-72.

Barneche, D. R., S. R. Floeter, D. M. Ceccarelli, D. M. B. Frensel, D. F. Dinslaken, H. F. S. Mário \& C. E. L. Ferreira. 2009. Feeding macroecology of territorial damselfishes (Perciformes: Pomacentridae). Marine Biology, 156: 289-299.

Bellwood, D. R. 1995. Direct estimate of bioerosion by two parrotfish species, Chlorurus gibbus and C. sordidus, on the Great Barrier Reef, Australia. Marine Biology, 121: 419-429.

Bonaldo, R. M., J. P. Krajewski, C. Sazima \& I. Sazima. 2006. Foraging activity and resource use by three parrotfish species at Fernando de Noronha Archipelago, tropical West Atlantic. Marine Biology, 149: 423-433.

Bruggemann, J. H. 1994. Parrotfish grazing on coral reefs: a trophic novelty. Unpublished M.Sc. Dissertation, University of Groningen, The Netherlands, 215p.

Chittaro, P. M., P. Usseglio, B. J. Fryer \& P. F. Sale. 2005. Using otolith microchemistry of Haemulon flavolineatum (French grunt) to characterize mangroves and coral reefs throughout Turneffe Atoll, Belize: difficulties at small spatial scales. Estuaries, 28: 373-381.

Choat, J. H. 1991. The biology of herbivorous fishes on coral reefs. Pp. 120-155. In: Sale, P. F. (Ed.). The ecology of fishes on coral reefs. San Diego, CA: Academic Press, 754p.

Dias, J. F., C. B. Fiadi, H. L. N. Silbiger \& L. S. H. Soares. 2005. Reproductive and population dynamics of the Bay whiff Citharichthys spilopterus Günther, 1862 (Pleuronectiformes: Paralichthyidae) in the Mamanguá Inlet, Rio de Janeiro, Brazil. Neotropical Ichthyology, 3: 411-419.

Dorenbosch, M., M. C. V. Riel, I. Nagelkerken \& G. V. D. Velde. 2004. The relationship of reef sh densities to the proximity of mangrove and seagrass nurseries. Estuarine, Coastal and Shelf Science, 60: 37-48.

Faunce, C. H. \& J. E. Serafy. 2006. Mangroves as fish habitat: 50 years of field studies. Marine Ecology Progress Series, 318: 1-18.

Ferreira, B. P. \& M. Maida. 2006. Monitoramento dos recifes de coral do Brasil - Situação Atual e Perspectivas. Brasília, MMA (Série Biodiversidade 18), 250p.

Ferreira, C. E. L., J. E. A. Gonçalves, R. Coutinho \& A. C. P. Peret. 1998. Herbivory by the Dusky Damselfish, Stegastes fuscus (Cuvier, 1830) in a tropical rocky shore: effects on the benthic community. Journal of Experimental Marine Biology and Ecology, 229: 241-264.

Ferreira, C. E. L., J. E. A. Gonçalves \& R. Coutinho. 2001. Fish community structure and habitat complexity in a tropical rocky shore. Environmental Biology of Fishes, 61: 353-369.

Ferreira, C. E. L., S. R. Floeter, J. L. Gasparini, B. P. Ferreira \& J. C. Joyeux. 2004. Trophic structure patterns of Brazilian reef fishes: a latitudinal comparison. Journal of Biogeography, 31 : 1093-1106.

Floeter, S. R., M. D. Behrens, C. E. L. Ferreira, M. J. Paddack, \& M. H. Horn. 2005. Geographical gradients of marine herbivorous fishes: patterns and processes. Marine Biology, 147: 1435-1447.

Floeter, S. R., W. Krohling, J. L. Gasparini, C. E. L. Ferreira \& I. R. Zalmon. 2007. Reef fish community structure on coastal islands of the southeastern Brazil: the influence of exposure and benthic cover. Environmental Biology of Fishes, 78: 147-160. 
Francini-Filho, R. B., C. M . Ferreira, E. O. C. Coni, R. L. Moura \& L. Kaufman. 2010. Foraging activity of roving herbivorous reef fish (Acanthuridae and Scaridae) in eastern Brazil: influence of resource availability and interference competition. Journal of the Marine Biological Association of the United Kingdom, 90: 481-492.

Froese, R. \& D. Pauly. 2010. World Wide Web electronic publication. Available from: http://www.fishbase.org (November 2010).

Gilbert, C. H. 1900. Results of the Branner-Agassiz Expedition to Brazil. III. The Fishes. Proceedings of the Washington Academy of Sciences 2: 161-184.

Gratwicke, B. \& M. R. Speight. 2005. The relationship between fish species richness, abundance and habitat complexity in a range of shallow tropical marine habitats. Journal of Fish Biology, 66: 650-667.

Gratwicke, B., C. Petrovic \& M. R. Speight. 2006. Fish distribution and ontogenetic habitat preferences in nonestuarine lagoons and adjacent reefs. Environmental Biology of Fishes, 76: 191-210.

Gray, J. S. 1997. Marine biodiversity: patterns, threats and conservation needs. Biodiversity and Conservation, 6: 153-175.

Guedes, A. P. P., F. G. Araújo \& M. C. C. Azevedo. 2004. Estratégia trófica dos linguados Citharichthys spilopterus Günter e Symphurus tessellatus (Quoy \& Gaimard) (Actinoperygii, Pleuronectiformes) na Baía de Sepetiba, Rio de Janeiro, Brasil. Revista Brasileira de Zoologia, 21: 857-864.

Horn, M. H. 1989. Biology of marine herbivorous fishes. Oceanography and Marine Biology: an Annual Review, 27: 167-272.

Ikejima, K., P. Tongnunui, T. Medej \& T. Taniuch. 2003. Juvenile and small fishes in a mangrove estuary in Trang province, Thailand: seasonal and habitat differences. Estuarine, Coastal and Shelf Science, 56: 447-457.

Ilarri, M. D. I., A. T. Souza, P. R. Medeiros, R. G. Grempel \& I. M. L. Rosa. 2008. Effects of tourist visitation and supplementary feeding on fish assemblage composition on a tropical reef in the Southwestern Atlantic. Neotropical Ichthyology, 6: 651-656.

Luckhurst, B. E. \& K. Luckhurst. 1978. Analysis of the inuence of the substrate variables on coral reef sh communities. Marine Biology, 49: 317-323.

Medeiros, P. R., R. G. Grempel, A. T. Souza, M. I. Ilarri \& C. L. S. Sampaio. 2007. Effects of recreational activities on the fish assemblage structure in a northeastern Brazilian reef. PanAmerican Journal of Aquatic Sciences, 2: 288-300.

Ministério do Meio Ambiente - MMA. 2002. Avaliação e ações prioritárias para a conservação da biodiversidade das Zonas Costeira e Marinha. Fundação Bio-Rio, SECTAM, IDEMA. Brasília, 72p.

Moberg, F. \& C. Folke. 1999. Ecological Goods and Services of Coral Reef Ecosystems. Ecological Economics, 29: 215-233.

Mourão, J. S. \& N. Nordi. 2003. Etnoecologia de pescadores artesanais do estuário do Rio Mamanguape, Paraíba, Brasil. Boletim do Instituto de Pesca, 29: 9-17.

Mourão, J. S. \& N. Nordi. 2006. Pescadores, Peixes, Espaço e Tempo: uma abordagem etnoecológica. Interciência, 31:358-363.

Mumby, P. J. \& A. Hastings. 2008. The impact of ecosystem connectivity on coral reef resilience. Journal of Applied Ecology, 45: 854-862.

Mumby, P. J., A. J. Edwards, J. E. Arias-González, K. C. Lindeman, P. G. Blackwell, A. Gall, M. I. Gorczynska, A. R. Harbone, C. L. Pescod, H. Renken, C. C. Wabnitz \& G. Llevellyn. 2004. Mangroves enhance the biomass of coral reef fish communities in the Caribbean. Nature, 427: 533-536.
Mumby, P. J., K. Broad, D. R. Brumbaugh, C. P. Dahlgren, A. R. Harborne, A. Hastings, K. E. Holmes, C. V. Kappel, F. Micheli \& J. N. Sanchirico. 2008. Coral Reef Habitats as Surrogates of Species, Ecological Functions, and Ecosystem Services. Conservation Biology, 22: 941-951.

Nagelkerken, I. \& C. H. Faunce. 2007. Colonization of artificial mangroves by reef fishes in a marine seascape. Estuarine, Coastal, and Shelf Science, 75: 417-422.

Nagelkerken, I. \& C. H. Faunce. 2008. What makes mangroves attractive to fish? Use of artificial units to test the influence of water depth, cross-shelf location, and presence of root structure. Estuarine, Coastal and shelf Science, 79: 559-565.

Nagelkerken, I., G. van der Velde, M. W. Gorissen, G. J. Meijer, T. van't Hof \& C. den Hartog. 2000. Importance of mangroves, seagrass beds, and the shallow coral reef as a nursery for important coral reef fishes, using a visual census technique. Estuarine, Coastal and Shelf Science, 51: 31-44.

Nagelkerken, I., S. J. M. Blaber, S. Bouillon, P. Green, M. Haywood, L. G. Kirton, J. O. Meynecke, J. Pawlik, H. M. Penrose, A. Sasekumar \& P. J. Somerfield. 2008. The habitat function of mangroves for terrestrial and marine fauna: A review. Aquatic Botany, 28: 155-185.

Ogden, J. C. \& E. H. Gladfelter. 1983. Coral reefs, seagrass beds and mangroves: their interaction in the coastal zones of the Caribbean. Montevideo, Unesco reports in marine science, $133 \mathrm{p}$.

Osório, F. M., W. O. Godinho \& T. M. C. Lotufo. 2011. Ictiofauna associada às raízes de mangue do estuário do Rio Pacoti - $\mathrm{CE}$, Brasil. Biota Neotropica, 11: 1-6.

Poot-Salazar, A., R. Pérez-Castañeda, M. E. Vega-Cendejas \& O. Defeo. 2009. Assessing patterns of ichthyofauna discarded by an artisanal shrimp fishery through selectivity experiments in a coastal lagoon. Fisheries Research, 97: 155-162.

Randall, J. E. 1967. Food habits of reef fishes of the West Indies. Studies in Tropical Oceanography, 5: 665-847.

Rocha, L. A., A. L. Bass, D. R. Robertson \& B. W. Bowen. 2002. Adult habitat preferences, larval dispersal, and the comparative phylogeography of three Atlantic surgeonfishes (Teleostei: Acanthuridae). Molecular Ecology, 11: 243-252.

Rocha, L. A., I. L. Rosa \& R. S. Rosa. 1998. Peixes recifais da costa da Paraíba, Brasil. Revista Brasileira de Zoologia, 15: 553-566.

Rocha, M. S. P., J. S. Mourão, W. M. S. Souto, R. R. D. Barboza \& R. R. N. Alves. 2008. O uso dos recursos pesqueiros no estuário do rio Mamanguape, Estado da Paraíba, Brasil. Interciência, 33: 903-909.

Rönnbäck, P. 1999. The ecological basis for economic value of seafood production supported by mangrove ecosystems. Ecological Economics, 29: 235-252.

Rosa, I. L., T. P. R. Oliveira, A. L. C. Castro, L. E. S. Moraes, J. H. A. Xavier, M. C. Nottingham, T. L. P. Dias, L. V. Bruto-Costa, M. E. Araújo, A. B. Birolo, A. C. G. Mai \& C. Monteiro-Neto. 2007. Population characteristics, space use and habitat associations of the seahorse Hippocampus reidi (Teleostei: Syngnathidae). Neotropical Ichthyology, 5: 405-414.

Rosa, R. S., I. L. Rosa \& L. A. Rocha. 1997. Diversidade da ictiofauna de pocas de mare da praia do Cabo Branco, João Pessoa, Paraíba, Brasil. Revista Brasileira de Zoologia, 14: 201-212.

Rosa, R. S. \& R. Sassi. 2002. Estudo da biodiversidade da Área de Proteção Ambiental Barra do Rio Mamanguape. Relatório Técnico Final. IBAMA, CNPq. João Pessoa, Universidade Federal da Paraíba, 371p. 
Silva, G. R. 2002. Estrutura da assembléia de peixes de poças de maré em Barra de Mamanguape, Rio Tinto, Paraíba, Brasil. Unpublished Msc. Dissertation, Universidade Federal da Paraíba, João Pessoa, 79p.

Souza, L. M. \& P. T. Chaves. 2007. Atividade reprodutiva de peixes (Teleostei) e o defeso da pesca de arrasto no litoral norte de Santa Catarina, Brasil. Revista Brasileira de Zoologia, 24: 1113-1121.

Souza, L. L. G., S. Chellappa \& H. C. B. Gurgel. 2007. Biologia Reprodutiva do peixe-donzela, Stegastes fuscus Cuvier, em arrecifes rochosos no nordeste do Brasil. Revista Brasileira de Zoologia, 24: 419-425.

Statsoft, Inc. 2004. Statistica (data analysis software system), version 6. www.statsoft.com.

Ter Braak, C. J. F. 1986. Canonical Correspondence Analysis: a new eigenvector technique for multivariate direct gradient analysis. Ecology, 67: 1167-1179.

Thomsom, D. A., L. T. Findley \& A. N. Kerstitch. 2000. Reef Fishes of the Sea of Cortez: the rocky shore fishes of Gulf of California. Austin, University of Texas Press, 355p.

Unsworth, R. K. F., S. L. Garrard, P. S. De León, L. C. Cullen, D. J. Smith, K. A. Sloman \& J. J. Bell. 2009. Structuring of Indo-Pacific fish assemblages along the mangrove-seagrass continuum. Aquatic Biology, 5: 85-95.

Weis, J. S. \& P. Weis. 2005. Use of intertidal mangrove and sea wall habitats by coral reef fishes in the Wakatobi Marine Park, Indonesia. The Raffles Bulletin of Zoology, 53: 119-124.

Williams, D. M. B. 1991. Patterns and processes in the distribution of coral reef fishes. Pp. 437-474. In: Sale, P. F. (Ed.). The Ecology of Fishes on Coral Reefs. San Diego, CA: Academic Press, 754p.

Submitted May 4, 2011

Accepted December 26, 2011

Published March 30, 2012 